\title{
A Case of Chronic Tonsillitis Mimicking a Parapharyngeal Space Tumor
}

\author{
Hyeon Seok $\mathrm{Oh}^{1}{ }^{1}$, Gyeong Hwa Jeon ${ }^{1}$, In Ho Choi ${ }^{2}$, and Hyung Kwon Byeon ${ }^{1}$ (D) \\ Departments of ${ }^{1}$ Otorhinolaryngology-Head and Neck Surgery and ${ }^{2}$ Pathology, Soonchunhyang University College of Medicine, \\ Seoul, Korea
}

\section{부인두강 종양으로 오인된 만성 편도염 1예}

오현석 ${ }^{1} \cdot$ 전경화 $^{1} \cdot$ 최인호 ${ }^{2} \cdot$ 변형권 $^{1}$

순천향대학교 의과대학 서울병원 ${ }^{1}$ 이비인후과학교실, ${ }^{2}$ 병리학교실

\author{
Received April 30, 2021 \\ Revised May 18, 2021 \\ Accepted May 21, 2021 \\ Address for correspondence \\ Hyung Kwon Byeon, MD, PhD \\ Department of Otorhinolaryngology- \\ Head and Neck Surgery, \\ Soonchunhyang University \\ College of Medicine, \\ 59 Daesagwan-ro, Yongsan-gu, \\ Seoul 04401, Korea \\ Tel $+82-2-709-9364$ \\ Fax $+82-2-709-9362$ \\ E-mail ewellcastle@gmail.com
}

Parapharyngeal space (PPS) tumors are extremely rare, composing only $0.5 \%$ of all head and neck tumors. The PPS is shaped like an inverted pyramid bounded by the skull base superiorly and hyoid bone inferiorly. Recently, we experienced a 55-year-old female patient who visited the clinic with a presumed PPS tumor that had been incidentally identified by neck MRI. The patient underwent surgery for the removal of tumor by transoral approach following tonsillectomy. However, contrary to the initial expectations, no tumors were visible at the operative field and only observed were the evidence of chronic inflammatory tissues within the removed tonsil. To date, chronic follicular tonsillitis mimicking a PPS tumor has not been reported in the literature. Therefore, we report this case with a brief discussion of points to consider supported by a review of relevant literature.

Korean J Otorhinolaryngol-Head Neck Surg 2021;64(11):834-8

\section{서 론}

부인두강의 종양은 두경부 영역에서 발생하는 종양의 약 $0.5 \%$ 를 차지하며 다양한 종류의 양성 및 악성종양이 존재한 다.1) 부인두강은 인두의 바깥쪽에 위치하는 공간으로 밑면이 두개저이고 설골을 꼭지점으로 하는 역피라미드 모양의 잠재 적 공간이다. 구개범장근과 경상돌기를 잇는 근막에 의해 전 외측공간인 전경상공간과 후내측 공간인 후경상공간으로 구 분된다. 전경상공간에는 주로 지방, 림프절, 이하선으로 구성 되어 있어 타액선 기원의 종양이 흔하며, 후경상공간에는 경 동맥과 내경정맥, 9-12번 뇌신경, 교감신경줄기 등으로 구성 되어 있어 신경원성 종양이 흔하다.,2)

This is an Open Access article distributed under the terms of the Creative Commons Attribution Non-Commercial License (https://creativecommons.org/licenses/by-nc/4.0) which permits unrestricted non-commercial use, distribution, and reproduction in any medium, provided the original work is properly cited.
부인두강 종양의 진단 방법으로 자기공명영상이나 전산화 단층촬영검사, 세침흡인세포검사 등이 이용되며, 부인두강 종 양의 수술 방법으로는 경이하선(transparotid), 경경부(transcervical), 또는 경이하선-경부(transparotid-cervical) 접근 법이 시행되며, 이외에도 두개 안면 접근법(craniofacial resection), 경구 접근법(transoral approach) 등이 있다.")

저자들은 수술 전 자기공명영상과 전산화단층촬영 검사를 통해 부인두강 종양이 의심되어 수술적 절제를 시행하였지만, 최종 조직학적인 결과상 단순 만성 편도염으로 진단한 증례 를 경험하였기에 문헌 고찰과 함께 보고하는 바이다.

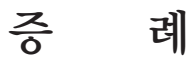

55 세 여자 환자가 내원 1 주일 전 시행한 두경부 자기공명영 상 검사에서 우연히 발견된 장경 $1.3 \mathrm{~cm}$ 크기의 우측 부인두 
강 종양을 주소로 외래에 내원하였다(Fig. 1). 기저질환으로 당뇨와 고지혈증에 대한 경구약 복용 외에는 특이사항이 없 었다. 부인두강 종양에 대한 경부 전산화단층촬영 검사상 구 인두 부위의 우측 부인두 공간에 각각 편도 조직과 주위 이 하선과는 분리되어 보이는 장경 $1.7 \mathrm{~cm}$ 크기의 종물이 확인 되었다(Fig. 2).

우측 부인두강 종양 제거술을 계획하여 전신마취하에 우
선 접근을 위해 다소 돌출된 우측 편도선을 제거하였다. 편도 조직이 전체적으로 편도 피막에 잘 둘러싸여진 채로 박리되 어 제거되었으며 편도와의 근육층을 침윤한 소견은 없었다. 이어서 편도와를 절개하여 부인두강 내로 진입하여 공간을 충분히 개방하여 종물 탐색을 수차례 시도하였으나 영상검 사상에서 보였던 종양은 촉지가 되거나 육안으로 관찰되지 않아 앞서 제거한 편도선의 동결절편 검사를 의뢰하였다. 그
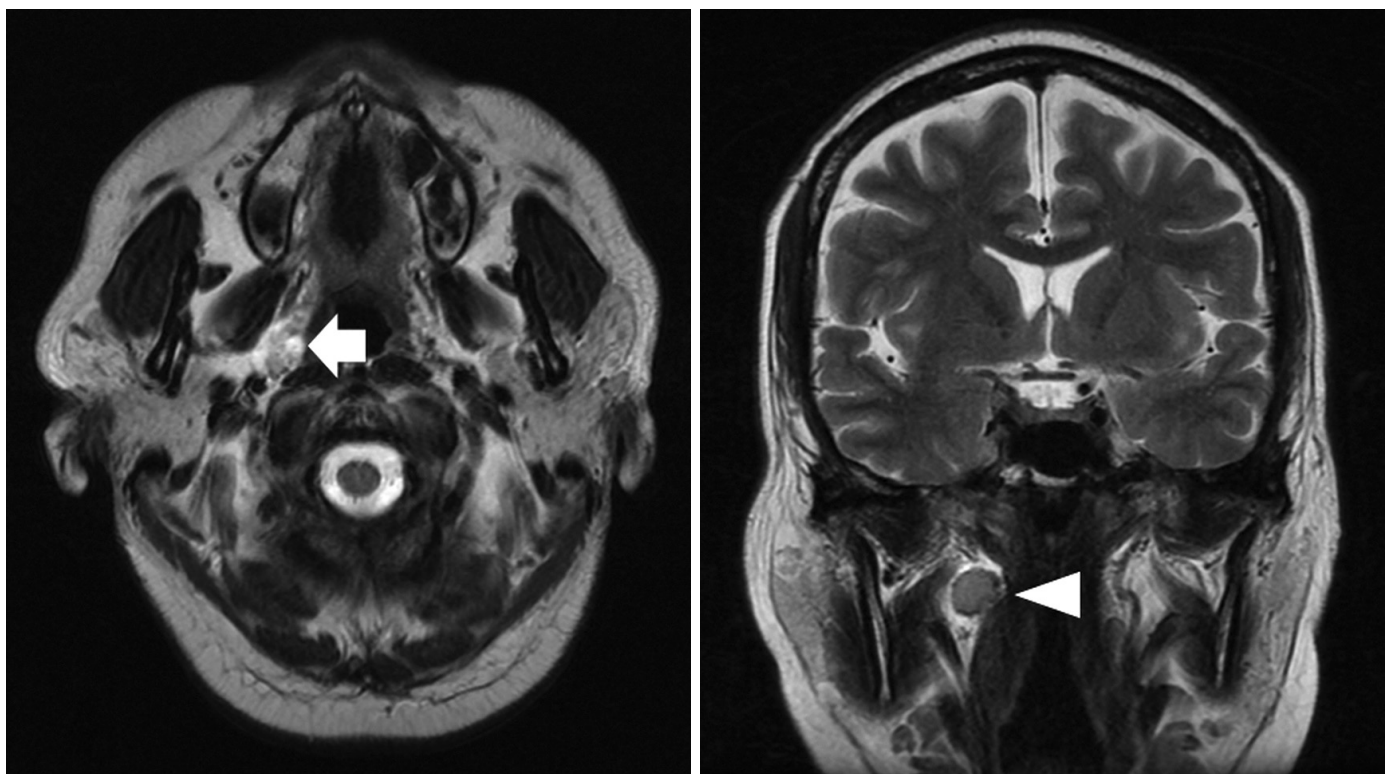

Fig. 1. Preoperative axial and coronal T2-weighted enhanced MR findings. About $1.4 \mathrm{~cm}$ sized well defined enhancing mass in right parapharyngeal area, oropharynx level (axial: arrow, coronal: arrowhead).
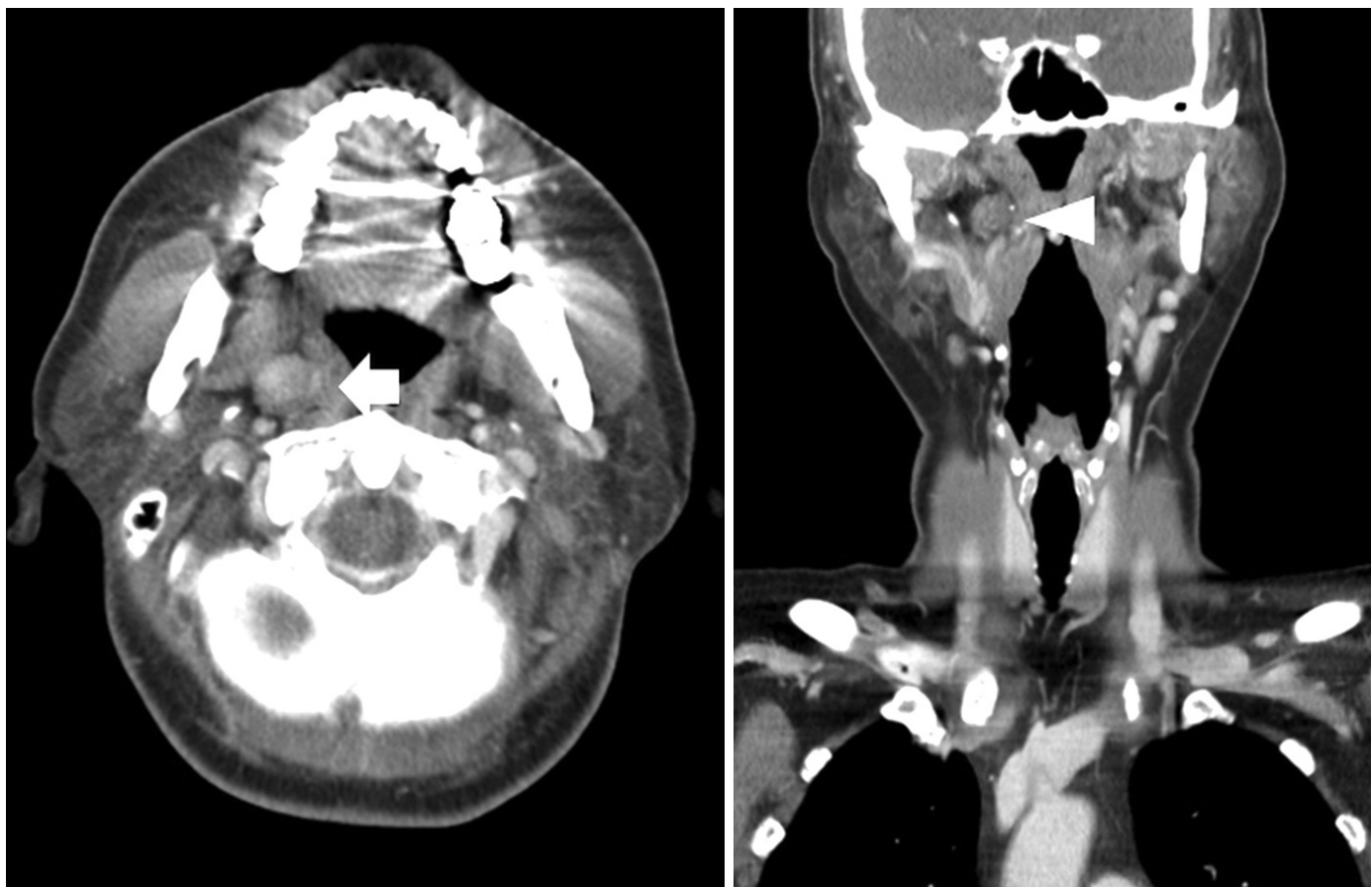

Fig. 2. Preoperative axial and coronal CT findings. About $1.7 \mathrm{~cm}$ sized well defined enhancing mass at right parapharyngeal space of oropharynx level (axial: arrow, coronal: arrow head). 
결과, 만성 편도염 조직 이외의 특이 종양 세포들은 당장 확 인되지 않아 최종 병리 검사 결과를 통해 확인하기로 하고 수술을 종료하였다(Fig. 3).

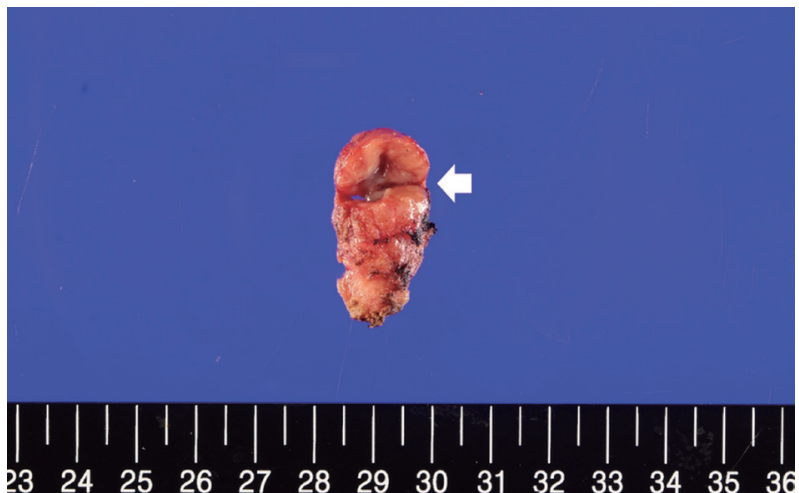

Fig. 3. Photograph of surgical specimen showing resected tonsil. The superior part of specimen has been transected by the surgeon to check the presence of any tumor (arrow).
수술 후 1 일째, 환자가 수술 부위의 지속적인 통증과 함께 갑자기 발생한 호전과 악화를 빠르게 반복하는 구음장애를 호소하였다. 구강설의 일반 감각, 맛 감각, 운동성 모두 이상 소견은 보이지 않았고, 연인두 폐쇄 부전 증상은 보이지 않았 다. 수술 직후 시행한 경부 전산화단층촬영 검사에서 이전 영 상에 확인하였던 종물 소견은 사라진 상태였으며, 수술 중 부 인두강의 절개 및 노출로 인하여 소량의 연부조직의 기종만 이 확인되었다. 이에 따라 중추성 신경학적 원인 감별을 위해 뇌 자기공명영상 촬영 검사를 시행하였으나 특이 이상 소견 은 확인되지 않았다. 이어 정신건강의학과와 연속적인 협의 진료를 하였는데 환자의 개인사회적 배경 및 수술 후 상당한 불안감을 느끼고 있는 점, 그리고 수술 후 2일째부터는 상기 증세가 급격하게 소실된 점을 미루어 보아 일시적인 신체화 증상(somatization)으로 진단되었다. 이후 수술 부위의 주기 적인 확인 및 약물 등 보존적인 치료를 지속하여, 수술 후 3일
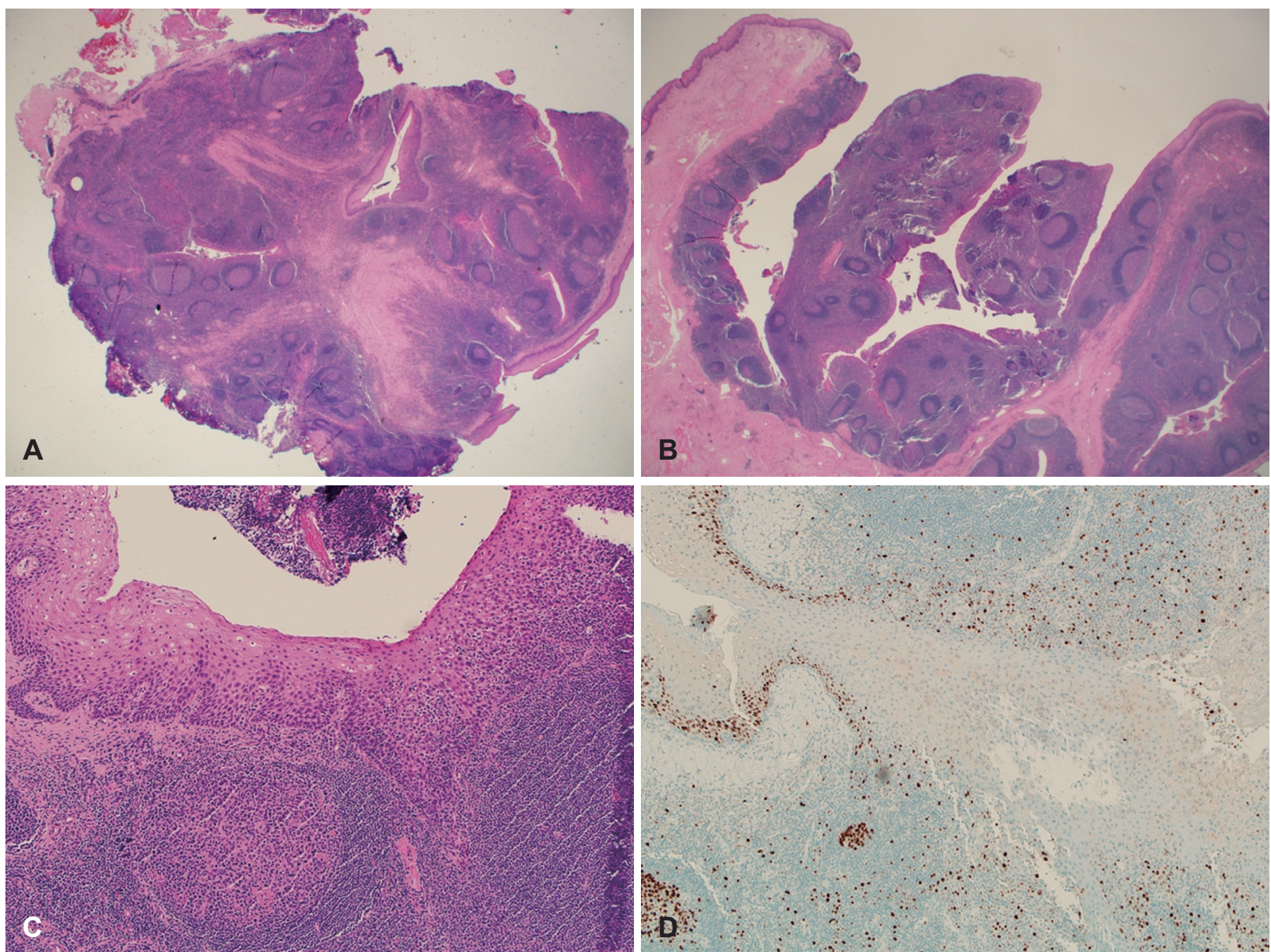

Fig. 4. Microscopic findings of parapharyngeal tonsil. A: At the low power view, the mass consists of predominant lymphoid tissue with central fibrosis $(H \& E, \times 12.5)$. B: Tonsilar crypts are surrounded by lymphoid stroma with many activated germinal centers $(H \& E, \times 40)$. C: Squamous epithelium lining crypts shows reactive cellular atypia in the area of increased lymphocytic infiltration (right side), and activated germinal centers are found in underlying lymphoid stroma (lower side) (H\&E, $\times 100)$. D: Ki-67 normally increased in the proliferative zone of the lining epithelium, and no findings suspicious of epithelial malignancy are found in the areas with mild cellular atypia (right side) $(\mathrm{Ki}-67, \times 200)$. H\&E, hematoxylin and eosin. 
째 수술 부위 통증이 완화되고 경구식이도 용이해지며 추가 적인 구음장애 증상이 보이지 않아 퇴원하였다. 적출된 종물 의 현미경 소견상, 비교적 경계가 좋은 병변으로 편도 음와 (tonsillar crypt)와 점막연관림프조직(mucosa-associated lymphoid tissue)이 잘 관찰되며, 병변의 중심부와 주변부의 섬유화를 동반하였다(Fig. 4A and B). 림프조직은 다수의 활 성화된 배 중심(activated germinal centers)이 확인되어 반 응성 병변의 소견을 보였고, 편도 음와를 덮고 있는 중층편평 상피는 국소적으로 경도의 반응성 세포이상 소견이 관찰되나, 악성 상피 내 종양을 의심할 만한 조직학적인 소견과 $\mathrm{Ki}-67$ 소견은 확인되지 않았다(Fig. $4 \mathrm{C}$ and D). 이상의 소견을 근거 로 부인두 편도의 만성 편도염으로 진단되었다. 영상학적 검 사에서 부인두강 종양으로 오인되었던 편도 상단 부위에 비 하여, 나머지 편도 하단 부위의 편도 조직에서 섬유화 조직의 분포가 조금 더 많은 것 이외에 조직학적 차이는 크게 없었다.

이후에 수술 후 4 개월째 시행한 경부 전산화단층촬영 검 사상에도 이전에 확인되었던 종물은 보이지 않음을 확인하 였다(Fig. 5).

\section{고 찰}

부인두강 종양의 임상양상은 무증상인 경우가 대부분으 로, 환자의 20\%-25\%가 증상 없이 우연히 발견된다고 보고된 바 있다. ${ }^{3,4}$ 본 증례에서 환자는 특별한 임상 증상은 호소하지 않았으며, 편도 및 주변 인두 부위, 경부의 비대는 보이지 않
았으나 자기공명영상 검사와 전산화단층촬영 검사에서 우연 히 발견된 우측 부인두강의 종물이 확인되었다. 이에 따라 부 인두강 종양을 의심하여 외과적 절제술을 계획하였고, 부인 두강 접근을 위해 다소 돌출된 편도를 절제한 이후에 편도 와를 절개하여 부인두강 종물 탐색을 하였으나 앞서 제거한 편도 조직 이외에 부인두강의 다른 종물은 발견되지 않았던 증례로, 결과적으로 편도 조직이 전체적으로 편도 피막에 잘 둘러싸여진 채로 박리되어 제거되었고 부인두강의 지방층과 연결된 양상도 보이지 않아, 편도 조직 상단 부위의 돌출된 부위가 부인두강 방향으로 밀리면서 영상학적 검사에서 부인 두강 종양처럼 보였던 것으로 추정된다.

본 증례와 같이 실제로는 종양성 병변이 아닌 것이 부인두 강 종양으로 오인된 사례가 드물게 보고된 경우가 있는데, Tonblison 등 ${ }^{5}$ 은 부인두강에 발생하는 정맥 기형(venous malformation)이 영상학적 검사에서 부인두강에 발생하는 다형선종(pleomorphic adenoma)과 유사하게 보여 감별이 어렵다고 보고하였다. Maruya 등 ${ }^{6}$ 은 영상학적 검사에서 확 인된 부인두강 종물에 대한 조직학적 검사를 통하여 염증성 거짓 종양(inflammatory pseudotumor)으로 진단하고 스테 로이드 치료를 통해 완치한 증례를 보고하기도 하였다.

편도 절제술은 이비인후과에서 가장 흔하게 시행되는 수술 중 하나로, 편도 절제술의 비교적 흔한 합병증으로는 출혈, 폐 부종, 치아손상, 구개인두 기능 부전 등이 있으며," 드문 합병 증으로는 내경동맥 손상, 설인신경의 손상, 피하기종 등이 있 다. ${ }^{8)}$ 부인두강 종양의 수술 후 발생할 수 있는 합병증으로는
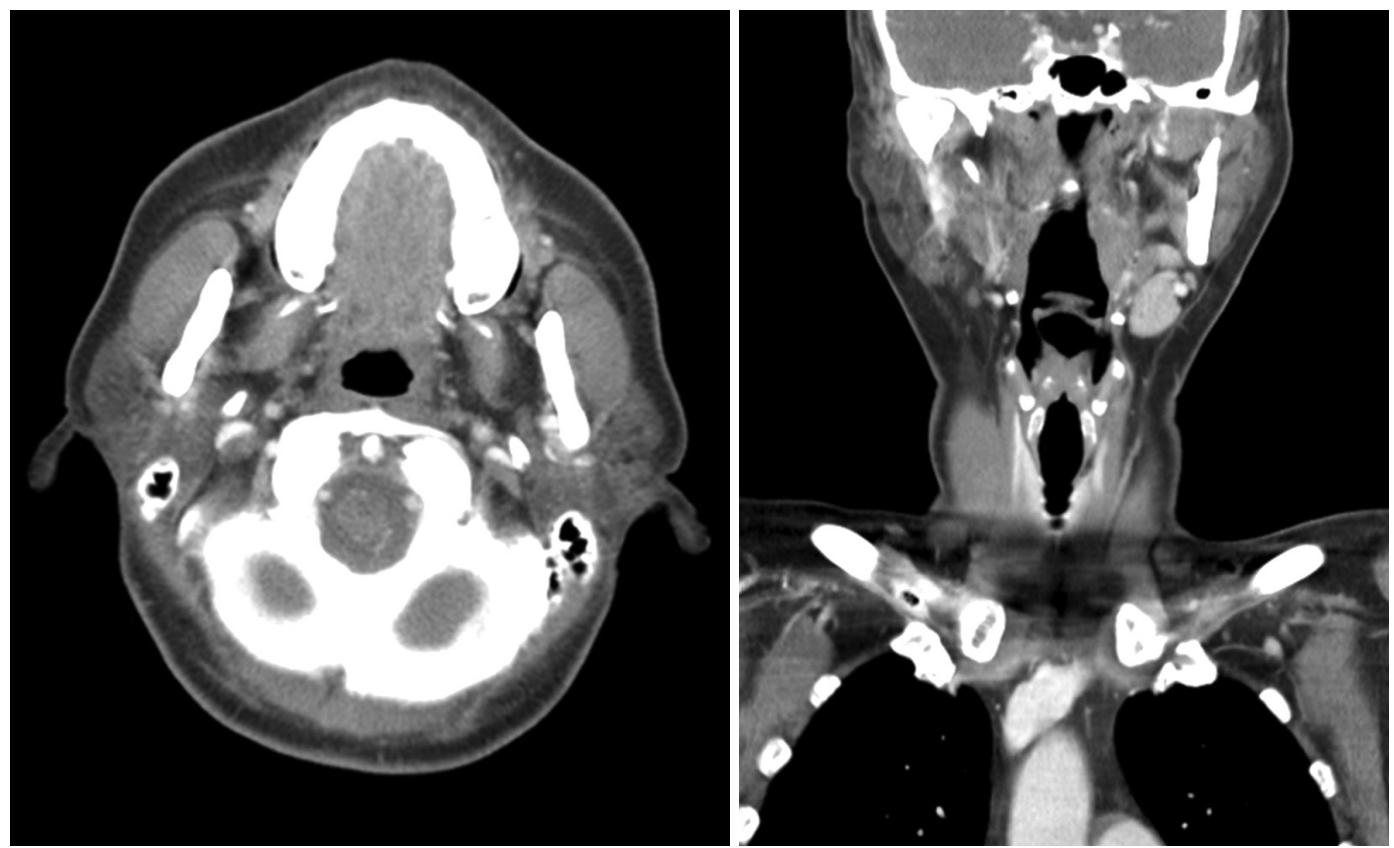

Fig. 5. Postoperative axial and coronal CT findings. There were no evidences of any tumorous lesions. 
Frey 증후군, 호너 증후군(Horner syndrome), 안면마비, 혀 마비, 성대마비, 인두마비 등이 있으며, 수술 후 동공 수축이 나 안검하수 여부, 안면 근육 운동, 혀 운동, 성대 운동, 승모 근과 흥쇄유돌근 운동 여부 등의 신경학적 검사를 통해 합병 증 여부를 확인해 볼 수 있다.9) 본 증례에서와 같이 경구강 수 술 후 환자가 갑자기 발생한 구음장애를 호소하는 경우에는 우선은 수술에 따른 합병증 혹은 중추성 신경학적 원인 등을 감별하기 위한 진찰과 검사를 진행하는 것이 중요할 것이다. 그러나 이와 같은 기질적인 원인의 가능성이 모두 배제가 된 경우에는 드물지만 본 증례처럼 신체화 증상 등 정신과적인 원인의 가능성도 염두에 두어야 할 것이다. 실제로 본 증례와 같은 경우가 아직까지 문헌에 보고된 경우는 없다.

저자들은 본 증례를 통해 편도 주변의 부인두강에 우연히 발견된 종물을 보이는 환자가 내원할 경우, 수술 전 영상 검 사에서 부인두강 종물을 의심하고 수술적 치료를 계획하더 라도, 편도 조직이 영상 검사에서 부인두강 종양처럼 보일 수 있기 때문에, 환자에게 수술에 대한 설명을 할 때 영상 검사 에서 부인두강 종양으로 의심되었던 종물이 편도나 다른 비 종양성 조직으로 확인될 수도 있음을 설명할 필요가 있을 것 으로 생각되어 문헌 고찰과 함께 보고하는 바이다.

\section{Acknowledgments}

None.

\section{Author Contribution}

Conceptualization: Hyung Kwon Byeon. Writing — original draft: Hyeon Seok Oh, Gyeong Hwa Jeon, In Ho Choi. Writing - review $\&$ editing: Hyung Kwon Byeon.

\section{ORCIDs}

Hyung Kwon Byeon https://orcid.org/0000-0003-3709-2028

Hyeon Seok Oh https://orcid.org/0000-0001-9361-0569

\section{REFERENCES}

1) Olsen KD. Tumors and surgery of the parapharyngeal space. Laryngoscope 1994;104(5 Pt 2 Suppl 63):1-28.

2) Batsakis JG, Sneige N. Parapharyngeal and retropharyngeal space diseases. Ann Otol Rhinol Laryngol 1989;98(4 Pt 1):320-1.

3) Carrau RL, Myers EN, Johnson JT. Management of tumors arising in the parapharyngeal space. Laryngoscope 1990;100(6):583-9.

4) Cohen SM, Burkey BB, Netterville JL. Surgical management of parapharyngeal space masses. Head Neck 2005;27(8):669-75.

5) Tomblinson CM, Fletcher GP, Lidner TK, Wood CP, Weindling SM, Hoxworth JM. Parapharyngeal space venous malformation: An imaging mimic of pleomorphic adenoma. AJNR Am J Neuroradiol 2019;40(1):150-3.

6) Maruya S, Miura K, Tada Y, Masubuchi T, Nakamura N, Fushimi $\mathrm{C}$, et al. Inflammatory pseudotumor of the parapharyngeal space: A case report. Auris Nasus Larynx 2010;37(3):397-400.

7) Johnson LB, Elluru RG, Myer CM 3rd. Complications of adenotonsillectomy. Laryngoscope 2002;112(8 Pt 2 Suppl 100):35-6.

8) Sachdeva K. Subcutaneous emphysema complicating tonsillectomy. World Articles in Ear, Nose and Throat 2013;6(1):1-4.

9) Ijichi K, Murakami S. Surgical treatment of parapharyngeal space tumors: A report of 29 cases. Oncol Lett 2017;14(3):3249-54. 